\title{
GROWTH PERFORMANCE OF GROWING PIGS FED DIETS CONTAINING PROBIOTICS AND PREBIOTICS
}

\author{
N. GROSU, lector universitar, Faculties of Agronomy, \\ E-mail: grosunatali@rambler.ru \\ L. CAISîN, PhD, interim university professor, Faculties of Agronomy \\ https://orcid.org/0000-0001-8934-2709 \\ E-mail: caisinlarisa@uasm.md \\ The State Agrarian University of Moldova
}

\begin{abstract}
The research undertaken in order to determine the efficacy of the use of additives "Vitacorm Bio Plus", was conducted on growing pigs. To conduct the experiment on the basis of analogies, two groups of clinically healthy pigs, 46 head each, were formed. The first group served as the control group, and received the basic diet; in the fodder for the second group the probiotic "Vitacorm Bio Plus»in quantities of $2.0 \mathrm{~kg} / \mathrm{t}$ was added. The supplementation of the mixed fodder with the "Vitacorm Bio Plus» $(2.0 \mathrm{~kg} / \mathrm{t})$ during the test period under production conditions has positively influenced the average daily gain of the young pigs during all growth periods (prestarter, starter, growing and finisher) respectively by $10.37 ; 2.51 ; 1.35$ and 10.83 $\%$; and the absolute and average daily gain over the whole test period by $5.52 \%$ and 5.65 $\%$ higher, with a feed consumption per $\mathrm{kg}$, with weight gain by $5.41 \%$ less compared to the animals in the CG. Compared to CG "Vitacorm Bio Plus» $(2.0 \mathrm{~kg} / \mathrm{t})$ carcase weight increased by $5.62 \%$, efficiency at hot slaughter by $4.94 \%$, and the thickness of the fat layer decreased in the neck region by $10.7 \%$, the fat layer at the 7 th thoracic vertebra decreased by $6.75 \%$ and in lumbar region by $8.97 \%$ compared to $C G$.
\end{abstract}

Ключові слова: бугаї, тип будови тіла, вираженість м'ясних форм, м'ясна худоба, відтворювальна здатність

\section{Introduction.}

The challenges that exist worldwide in terms of productivity, ensuring animal health and, consequently, food security, also concern the ecological systems of animal husbandry practiced both in the member countries and in the candidate countries of the European Union. Numerous studies have shown that while organic farming provides better conditions for obtaining uncontaminated animal products at the same time as animal welfare, it presents a much higher risk of infectious and parasitic diseases compared to conventional livestock systems.

The market for nutritional supplements is invaded by various lesser-known products among breeders. This category includes prebiotics, substances that support or favor the development and multiplication of probiotic microorganisms (Pervova, 2008). 
The use of additives in the combined feeds is therefore a necessity, in order to obtain high yields. Further research is needed to identify the positive effects and minimize the negative effects that they may have if not used properly. In particular, additives will play a vital role in maintaining the health of livestock in the future without pharmaceuticals.

\section{Materials and methods.}

The obtaining of the zootechnical performances at the level of the genetic potential is influenced by the rational feeding of the pigs, of optimized recipes that would satisfy the nutritional requirements.

In accordance with the purpose and for the solution of the tasks, a biological experiment was initiated for testing the probiotic and prebiotic «Vitacorm Bio Plus» in the feeding of pig under production conditions within the $« \mathrm{Bu}-$ covăţ» pig farm. The animals under experiment were divided into two homogeneous groups by age, body weight (Ovsianicov, 1976; Pocerneaev, 1977), respectively the control group (CG) and the experimental group (EG), (tab.1).

The maintenance of the animals from both experimental and control groups was identical. They had the same microclimate according to the sanitary-veterinary norms as well as similar fodder three times a day, with access to water at discretion. The difference was in the ad- ditional introduction of the «Vitacorm Bio Plus» (at a level of $2.0 \mathrm{~kg} / \mathrm{t}$ mixed feed in the experimental group (EG).

Mixed feed recipes (tab. 2) have been elaborated and optimized from the nutritional and economic point of view in accordance with the nutritional requirements, adapted to the physiological state and the age of the animals (Calashnicov, 2003; Petuhova and Bessarabov, 1989).

Within the researches regarding the influence of combined feed recipes and the preparation «Vitacorm Bio Plus» on the productive performances of the pigs, the growth performances were evaluated: body weight, average daily gain during growth periods by individual weighing of animals using electronic scales, individually (Victorov and Menchin, 1991; Antipova et al., 2001).

In order to determine the influence of the studied factors on the yield and quality of the meat production at the end of the approval experiments under production conditions, control was carried out on three animals from each group, reaching the body mass of pigs for slaughter, having an average development according to GOST 53221-2008.

In the study the following parameters were taken: live weight, carcass mass, yield on hot slaughter, mass of semi-carcasses, thickness of the fat layer along the spine measured with the metallic ruler with millimetre divisions, the surface of the «muscle eye» of Longissimus

\section{Scheme of experience}

\begin{tabular}{|l|c|c|}
\hline \multicolumn{1}{|c|}{ Group } & Number of heads & Feeding peculiarities \\
\hline Control (CG) & 46 & BD - basal diet \\
\hline Experimental (EG) & 46 & BD $+2.0 \mathrm{~kg} / \mathrm{t}$, ,Vitacorm Bio Plus” $\left.{ }^{\mathrm{x}}\right)$ \\
\hline
\end{tabular}

${ }^{x}$ Composed of: highly activated hemicellulose, lignin, pectin, bentonite, humic acids, complex macro- micronutrients in chelated form; it is a complex supplement that combines the properties of probiotic microorganisms based on Lactobacillus $1 \times 107$ 


\section{Structure of the mixed feed, $\%$}

\begin{tabular}{|l|c|c|c|}
\hline \multirow{2}{*}{ Composition } & \multicolumn{3}{c|}{ Experimental period } \\
\cline { 2 - 4 } & Prestarter-starter & Grower & Finisher \\
\hline Corn & 13.0 & 14.0 & 23.0 \\
\hline Extruded corn & 10.0 & - & - \\
\hline Wheat & 11.0 & 18.0 & 21.5 \\
\hline Extruded wheat & 10.0 & - & - \\
\hline Barley & 11.5 & 32.0 & 21.5 \\
\hline Extruded barley & 10.0 & - & - \\
\hline Extruded peas & 10.0 & 5.5 & 10.0 \\
\hline Sunflower cakes & 6.0 & 10.0 & 7.5 \\
\hline Soybean groats & 9.0 & - & 7.0 \\
\hline Wheat bran & 5.0 & 16.5 & 5.0 \\
\hline Premix „Biomin” & - & 2.5 & 2.5 \\
\hline Premix „Nutristar” & 2.5 & - & - \\
\hline Feed chalk & 1.65 & 1.15 & 1.65 \\
\hline Salt & 0.35 & 0.35 & 0.35 \\
\hline
\end{tabular}

\section{Nutrients concentration in $1 \mathrm{~kg}$ of mixed feed}

\begin{tabular}{|l|c|c|c|}
\hline \multirow{2}{*}{ Nutritional parameters } & \multicolumn{3}{c|}{ Experimental period } \\
\cline { 2 - 4 } & Prestarter-starter & Grower & Finisher \\
\hline Oats nutritional units & 1.17 & 1.1 & 1.17 \\
\hline Metabolic energy, Mj & 10.31 & 10.09 & 10.29 \\
\hline Crude protein, g & 159.05 & 151.93 & 160.23 \\
\hline Degradable protein, g & 126.62 & 115.47 & 127.80 \\
\hline Crude fiber, g & 47.02 & 54.45 & 46.87 \\
\hline Lysine, g & 6.10 & 5.16 & 6.13 \\
\hline Methionine + Cystine, g & 4.85 & 4.81 & 4.91 \\
\hline Calcium, g & 1.71 & 1.88 & 1.72 \\
\hline Phosphorus, g & 5.24 & 5.73 & 5.23 \\
\hline
\end{tabular}

dorsi muscle by outlining the muscle on millimetre calk paper for surface calculation. The carcasses were cut according to the method described by Cucu et al. (2004) and Caisîn et al. (2013).

All the obtained data were statistically processed (Plohinschi, 1969) using the computer program EXCEL.

\section{Results and discussions.}

The dynamics of the body weight show that in all the periods of age, the growth intensity of the young pigs was quite high, which reveals the positive effect of the supplementation of the mixed feeds with pro-prebiotic prepara- 


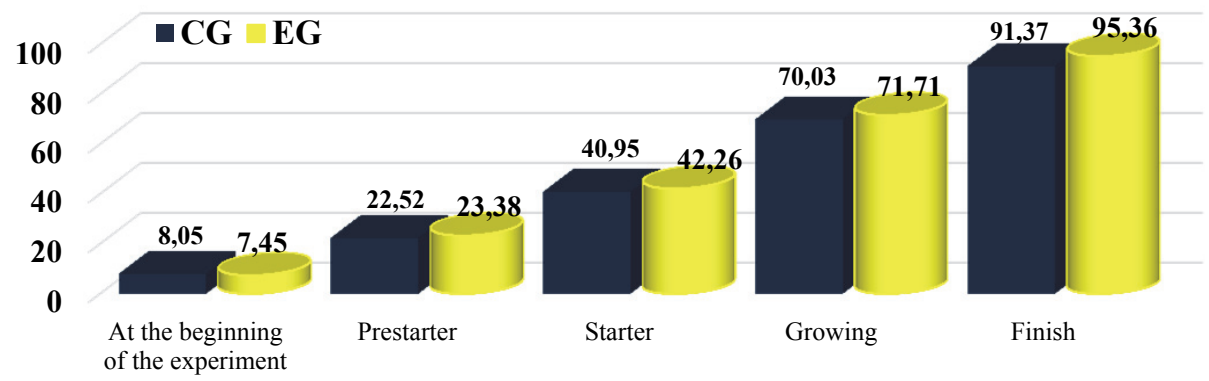

Fig. 1. Dynamics of body weight during the experimental period, $\mathrm{kg}$

tions. Differences were noted between the groups of piglets during all age periods (fig. 1). The presented data show that the young pigs from EG who received additional pro-prebiotic preparation «Vitacorm Bio Plus» at the level of $2.0 \mathrm{~kg} / \mathrm{t}$ mixed feed at the beginning of the experiment had a lower mass compared to CG by $0.20 \mathrm{~kg}$.

Starting with the end of the prestarter period, a prevalence of the body weight by $3.82 \%$ is observed, at the end of the starter period by $3.20 \%$, at the end of the growing period by $2.40 \%$ and at the end of the finish period by $4.37 \%$.

An important component in determining the growth intensity is represented by the average daily gain, calculated over all experimental periods and represented in fig. 2.

It has been established that the average daily gain was influenced by the

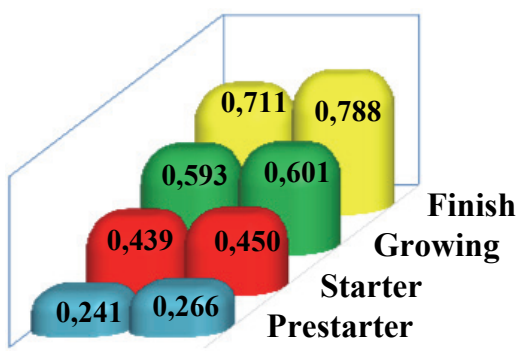

\section{LM LE}

Fig. 2 . The average daily gain, $\mathrm{kg}$ pro-prebiotic «Vitacorm Bio Plus» for all periods of the young pigs growth in EG indicating a difference of 10.37; $2.51 ; 1.35$ and $10.83 \%$ respectively during the prestarter, starter, growing and finish periods.

At the end of the experiment the absolute gain was calculated throughout the experiment period (fig. 3).

The absolute gain was obtained on average during the experimental period in CG of young pigs at $83.32 \mathrm{~kg}$, which is by $4.60 \mathrm{~kg}$ or $5.52 \%$ less compared to EG of young pigs who received pro-prebiotic «Vitacorm Bio Plus».

One of the basic objectives in the production approval was to find the efficiency of using the mixed feed supplemented with pro-prebiotic preparations. Based on the data obtained during the production approval, we have found out that feeding young pigs with mixed feed supplemented with pro-prebiotic preparations influenced the use of nutrients in

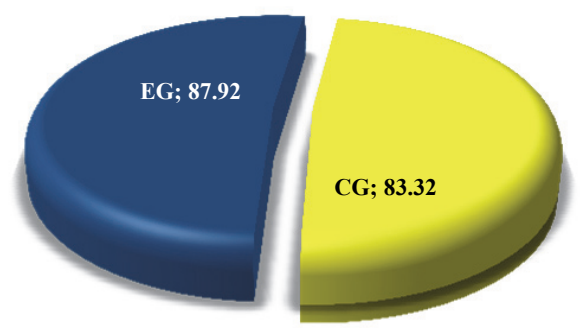

Fig. 3. The absolute gain, kg 


\section{The conversion of the mixed feed during the tests}

\begin{tabular}{|c|l|c|c|}
\hline \multirow{2}{*}{ № } & \multicolumn{2}{|c|}{ Parameters } & \multicolumn{2}{c|}{ "Vitacorm Bio Plus" } \\
\cline { 3 - 4 } & & CG & EG \\
\hline 1 & Feed consumption during the experiment, kg / head & 286,80 & 286,22 \\
\hline 2 & Average daily feed consumption, kg/head & 1,585 & 1,581 \\
\hline 3 & Feed conversion per 1kg of gain weight, $\mathrm{kg}$ & 3,442 & 3,256 \\
\hline 4 & Difference compared to control, \% & - & $-5,41$ \\
\hline
\end{tabular}

5. Productive performances of young pigs for slaughter, $\bar{X}+S \bar{x}$

\begin{tabular}{|l|c|c|c|c|c|}
\hline Group & $\begin{array}{c}\text { Mass before } \\
\text { slaughter, } \mathrm{kg}\end{array}$ & $\begin{array}{c}\text { Carcass mass, } \\
\mathrm{kg}\end{array}$ & Slaughter yield, $\%$ & $\begin{array}{c}\text { Mass of the right } \\
\text { semi-carcass, kg }\end{array}$ & $\begin{array}{c}\text { Mass of the left } \\
\text { semi-carcass, } \mathrm{kg}\end{array}$ \\
\hline CG & $104,33 \pm 0,88$ & $76,40 \pm 0,59$ & $73,23 \pm 0,06$ & $37,58 \pm 0,37$ & $38,82 \pm 0,27$ \\
\hline EG & $105,00 \pm 1,73$ & $80,70 \pm 1,76^{*}$ & $76,85 \pm 0,47^{* * *}$ & $39,43 \pm 0,92$ & $41,27 \pm 0,84 * *$ \\
\hline
\end{tabular}

* - $\mathrm{P}<0,10 ; * *$ - $\mathrm{P}<0,05 ; * * *-\mathrm{P}<0,01$

the animal body for production, which is positively reflected on feed costs. During the approval test, the pro-prebiotic «Vitacorm Bio Plus» is used in EG at $286.22 \mathrm{~kg}$, which is $0.20 \%$ less compared to $\mathrm{CG}$.

Using the data on feed consumption and the absolute gain obtained during the test period, it has been determined that the feed was converted to $1 \mathrm{~kg}$ of weight gain; it has been established that EG which received additional preparation «Vitacorm Bio Plus» had a feed conversion of $5.41 \%$ over animals from CG.

One of the main indicators that characterized the results of the pigs' growth is the slaughter yield which is determined by the percentage ratio between the carcass mass and the live mass. According to our research, the priority of the animals from the experimental groups was established compared to the control groups according to the warm carcass mass as well as to the semi-carcasses.

Warm weighed carcasses have a weight of $76.40 \mathrm{~kg}$ on average in CG and $80.70 \mathrm{~kg}$ in $\mathrm{EG}$, which represents a difference of $4.30 \mathrm{~kg}$ or $5.62 \%$ compared to $\mathrm{CG}$ in the case of supplementation of the mixed feed with the pro-prebiotic «Vitacorm Bio Plus» at $2.0 \mathrm{~kg} / \mathrm{t}$ level in the pigs from EG.

At the same time, it has been found out that the slaughter yield in EG that received the pro-prebiotic «Vitacorm Bio Plus» was higher than in the control group CG respectively by $4.94 \%$, statistical data being (tab. 5).

The thickness of the fat layer in pigs depends not only on the belonging to the breed and on the selection work carried out but also on the quality level of the nutrition (table 8).

Analyzing the data regarding the thickness of the fat layer, a decrease was found throughout the upper line of the carcass (tab. 6).

As we can see under the influence of the pro-prebiotic «Vitacorm Bio Plus» in the neck region the thickness of the fat layer decreased by $3.00 \mathrm{~mm}(10.7 \%)$, statistically authentic, in the region of the 7 th thoracic vertebra by $1.67 \mathrm{~mm}$ or $6.75 \%$ respectively and in the lumbar region by $2.33 \mathrm{~mm}(8.97 \%)$, less than in the animals from the control group (CG). 
6. The thickness of the fat layer, $\mathbf{m m}\left(\bar{X}_{ \pm} \mathrm{S}_{\bar{x}}\right)$

\begin{tabular}{|l|c|c|c|}
\hline \multirow{2}{*}{ Group } & \multicolumn{3}{|c|}{ Thickness, mm } \\
\cline { 2 - 4 } \multicolumn{2}{|c|}{ at the 7th vertebra } & neck region & lumbar region \\
\hline CG & $24,667 \pm 1,45$ & $28,000 \pm 0,58$ & $26,000 \pm 0,58$ \\
\hline EG & $23,000 \pm 1,73$ & $25,000 \pm 1,00^{*}$ & $23,667 \pm 0,67^{*}$ \\
\hline
\end{tabular}

* - $\mathrm{P}<0,10$

\section{Conclusions}

The supplementation of the mixed feed with the «Vitacorm Bio Plus» $(2.0 \mathrm{~kg} / \mathrm{t})$ during the test period under production conditions has positively influenced the average daily gain of the young pigs during all growth periods (prestarter, starter, growing and finish) respectively by $10.37 ; 2.51 ; 1.35$ and $10.83 \%$; and the absolute and average daily gain over the whole test period by $5.52 \%$ and $5.65 \%$ higher, with a combined feed consumption per $\mathrm{kg}$, with weight gain by $5.41 \%$ less compared to the animals in the CG.

Compared to $\mathrm{CG} »$ Vitacorm Bio Plus» $(2.0 \mathrm{~kg} / \mathrm{t})$ carcase weight increased by $5.62 \%$, efficiency at hot slaughter by $4.94 \%$, and the thickness of the fat layer decreased in the neck region by $10.7 \%$, the fat layer at the 7th thoracic vertebra decreased by $6.75 \%$ and in lumbar region by $8.97 \%$ compared to CG.

Having analysed the data obtained during the experiment it can be proposed to use combined fodder supplemented with the pro-prebiotic preparation «Vitacorm Bio Plus» in the amount of $2.0 \mathrm{~kg} / \mathrm{t}$ in the process of raising young pigs.

\section{References}

1. Antipova, L., Glotova, I., Rogova I. (2001). Research methods of meat and meat products. Kolos, Moscow. p. 233-361.

2. Caisin, L., Harea, V. (2013). Methodology and technology research on feeding pigs. Chisinau, p. 168-177.

3. Calashnicov, A., (2003). Norms and rations for feeding farm animals. Moscow, $374 \mathrm{p}$.

4. Cucu, I., Maciuc, V., Maciuc, D. (2004). Scientific research and experimental technique elements. Iashi, Alpha Publishing House, $388 \mathrm{p}$.

5. GOST 53221-2008. Pigs for slaughter. Pork carcasses and semi-carcasses. Specifications.

6. Ovsianicov, A., (1976). Fundamentals of experimental work in animal husbandry. Moscow, $304 \mathrm{p}$.

7. Pervova, A. (2008). Cellobacterin in compound feeds for broiler chickens: PhD thesis, Sergiev Posad, $154 \mathrm{p}$.

8. Petuhova, E., Bessarabov R., (1989). Zootechnical analysis of feed, Moscow, Kolos, $258 \mathrm{p}$.

9. Plohinschi, P., (1969). Biometrics guide for livestock specialists. Moscow, $255 \mathrm{p}$.

10. Pocerneaev, F., (1977). Pigs breeding research methods. Haricov, $151 \mathrm{p}$.

11. Victorov, V., Menchin A., (1991). Methodology of experimental work in animal husbandry. Moscow, $112 \mathrm{p}$.

\section{Н. ГросУ, Л. КайсИН (2020). РЕЗУЛЬТАТИ ВИРОЩУВАННЯ МОЛОДНЯКУ СВИНЕЙ ІЗ ВКЛЮЧЕННЯМ ДО РАЦІОНІВ ПРОБІОТИКІВ І ПРЕБІОТИКІВ. АNІMАL SCIENCE AND FOOD TECHNOLOGY, 11(1): 17-23. https://doi.org/10.31548/ animal2020.01.017.}


Анотація. Дослідження проведені з метою визначення ефективності використання добавок "Vitacorm Bio Plus». Для проведення експерименту за методом аналогів було срормовано дві групи клінічно здорових свиней, по 46 голів у кожній. Перша група була контрольною і отримувала основний раціон. В комбікорм для другої (дослідної) групи додавали про-пребіотик "Vitacorm Bio Plus» у кількості 2,0 кг на 1 т. В рамках досліджень оцінювали показники росту молодняку свиней, зокрема живу масу і середньодобовий приріст шляхом індивідуального зважування з використанням електронних вагів. 3 кожної групи проводили контрольний забій трьох тварин, що досягали живої маси забою та мали середній розвиток. Після забою визначали масу та вихід парної туші, масу напівтуші, товщину шпику вздовж хребта (металевою лінійкою з міліметровими поділами), плошу «м'язового вічка» longissimus dorsi (шляхом окреслення м'яза на міліметровому папері). Порівняно з тваринами в контрольній групі, включення до комбікорму «Vitacorm Bio Plus» позитивно вплинула на середньодобовий приріст молодняку свиней протягом усіх періодів вирощування (престартер, стартер, дорощування та відгодівля) відповідно на 10,37; 2,51; 1,35 і 10,83 \%. Абсолютний і середньодобовий приріст за весь період випробування в дослідній групі був вище на 5,52 \% і на 5,65 \%, за менших на 5,41 \% витратах корму на кг приросту. Включення в комбікорм «Vitacorm Bio Plus» сприяло збільшенню маси туші на 5,62 \%, виходу парної туші на 4,94 \%, але товщина жирового шпику зменшилася, зокрема в ділянці шиї, на 10,7\%, в ділянці 7-го грудного хребия - на 6,75 \%, і поперековій області - на 8,97\%. Дані отримані під часі експерименту підтверджують доцільність використання для вирощування свиней комбікормів з про-пребіотичним препаратом «Vitacorm Bio Plus» у кількості 2,0 кг на $1 \mathrm{~m}$.

Ключові слова: свині, про-пребіотик, середньодобовий приріст, жива маса, маса туші, товщина шпику 